\title{
'A place for men to come and do their thing': constructing masculinities in betting shops in London ${ }^{1}$
}

\author{
Rebecca Cassidy
}

\begin{abstract}
During fieldwork conducted with workers and customers in betting shops in London research participants consistently conceptualized betting shops as masculine spaces in contrast to the femininity of other places including home and the bingo hall. According to this argument, betting on horses and dogs was 'men's business' and betting shops were 'men's worlds'. Two explanations were offered to account for this situation. The first suggested that betting was traditionally a pastime enjoyed by men rather than women. The second was that betting is intrinsically more appealing to men because it is based on calculation and measurement, and women prefer more intuitive, simpler challenges. I use interviews with older people to describe how the legalisation of betting in cash in 1961 changed the geography of betting. I then draw upon interviews with regular customers in order to show how knowledge about betting is shared within rather than between genders. Finally, I use my experience of training and working as a cashier to describe how the particular hegemonic masculinity found in betting shops in London is maintained through myriad everyday practices which reward certain kinds of gendered performances while at the same time suppressing alternatives. The article shows how particular spaces may become gendered as an unanticipated consequence of legislation and how contingent gendered associations are both naturalized and, at the same time, subjected to intense attention.
\end{abstract}

Keywords: Betting shops; London; gender; hegemonic masculinity; geography of masculinity; ethnography

\section{Introduction}

The casual reinforcement of an association between betting on horse racing and a particular kind of masculinity is ubiquitous in the UK. Former

Cassidy (Department of Anthropology, Goldsmiths College, London) (Corresponding author email: r.cassidy@gold.ac.uk) (Corresponding author email: r.cassidy@gold.ac.uk)

(C) London School of Economics and Political Science 2013 ISSN 0007-1315 print/1468-4446 online.

Published by John Wiley \& Sons Ltd, 9600 Garsington Road, Oxford OX4 2DQ, UK and 350 Main Street, Malden,

MA 02148, USA on behalf of the LSE. DOI: 10.1111/1468-4446.12044 


\section{Rebecca Cassidy}

bookmaker and Old Harrovian, John McCririck, the larger than life television racing pundit, refers to his wife as 'The Booby' and his co presenter and fellow tipster as 'Female'. Tanya Stevenson ('Female') has also been described as 'A Maiden for the notebook' in a headline in The Daily Telegraph written by journalist and former jockey Marcus Armytage (2001, see also Potter 2004). Scottish bookmaker Kelly Martin, referred to on the BBC News website as 'Tall, blonde and rather more attractive than John McCririck' told her interviewer that she had achieved her greatest victory when a fellow bookmaker turned to her and said, 'I don't see you as a woman - I see you as a bookie' (quoted by Goodlad 2008). In receiving this accolade, Martin has achieved the fragile 'female masculinity' (Halberstam 1998) that the gambling and racing industry considers necessary for women to practice bookmaking. The gendering of betting on horseracing is maintained in different ways across a range of spaces in the UK including racecourses, training yards and thoroughbred studs (Cassidy 2002). It crystallizes with particular force in specialist high street shops where betting on horses, dogs and sports is routinely described as 'men's business', and betting shops as 'a man's world'. In this article I use ethnographic data to explore this association in more detail, and offer explanations for its tenacity. I focus on the betting shop environment, the mechanisms through which knowledge about betting is transmitted and the geography of masculinity these exchanges create.

In 1987, Connell described hegemonic masculinity as 'the maintenance of practices that institutionalize men's dominance over women . . constructed in relation to women and to subordinate masculinities' (1987: 185-6). Reformulating the concept in 2005, Connell and Messerschmidt acknowledge that its least critical uses generated trait models of gender and typologies that were unhelpfully rigid. These approaches failed to recognize that hegemonic masculinities were framed in relation to subordinate masculinities and emphasized femininities (1987: 829). Connell and Messerschmidt's reworked concept (2005) reflects a more dynamic model of gender hierarchy which encompasses local and global forces and processes, a greater sense of gendered spaces, embodiment and resistance. Rather than postulating a singular hegemonic masculinity, Messerschmidt suggests, research employing this new concept should analyse hegemonic masculinities at three levels: local, regional, and global (2012: 59). In this article I apply the reformulated concept to the local level of betting shops in London without suggesting that this level can be entirely divorced from the national or regional level at which regulation takes place, or from the global context in which ideas about gambling circulate.

Betting shops in London, like the trading floors of investment banks (Levin 2004) and sex bars in Finland (Pentinnen 2008: 115), are examples of 'masculine spaces', defined by Gottdeiner as 'places where traditionally men have congregated more commonly than women and where males are at a distinct advantage regarding the deployment of power' (2005: 81, see also van Hoven 
and Hoerschelmann 2005). This article focuses on the dynamic qualities of these spaces, and how a particular hegemonic masculinity is legitimated and actively 'cultivated' (Messerschmidt 2012: 64). Working with South African female undergraduates, Talbot and Quayle have argued that the maintenance of hegemonic masculinities requires, "at least some kind of "buy-in" from women' (2010: 256). In this article I show how women contribute to the cultivation of hegemonic masculinity in betting shops by attributing different qualities to men and women, but also how these ideas are context specific, contested and resisted.

\section{Methods}

This article draws on two streams of fieldwork undertaken in London between 2006 and 2009. The first consisted of spending time hanging out in various shops talking with customers (known as 'punters'). The second involved training and working as an unpaid cashier for two different firms: a small ambitious chain and an established market leader. I gained access to the small firm after a chance meeting with a senior management figure at a betting conference and to the second by approaching the Association of British Bookmakers. The small firm was very open: I was encouraged to interview and work shadow all of their thirty employees. The large firm was less enthusiastic. Despite this, I was fortunate in being sent to a central London shop where the manager included me in every aspect of the day to day running of the shop over a period of two months.

Before I undertook my training as a cashier, I spent two months visiting more than a hundred shops in London, having conversations with staff and customers. I then chose sixteen locations (from large flagship stores in prestigious sites to small, relatively neglected shops in quiet side streets) and spent up to three periods of six hours in each, observing daily routines. Spending long periods of time in shops enabled me to develop rapport with my participants and to become part of the environment, reducing my impact on behaviour (which none the less remained the product of a unique research encounter). I was able to compare what people told me about their activities with what they actually did and to record how their behaviour changed through time and across different spaces. No deliberately covert fieldwork was undertaken, although it is possible that some of the people I observed in shops were unaware of the reason for my presence.

Data gathered included a daily diary of events and interactions, time and motion studies of betting patterns, recorded interviews and discussions with groups and individuals. Interviews took a number of different forms. Some were organized in advance and took place outside the betting shop, including those with fifteen betting shop managers. I conducted life history interviews 


\section{Rebecca Cassidy}

with twenty of the eighty punters identified as key participants in this article. During these interviews we constructed personal history lines recording gambling and other life events. Discussions with key participants were open ended and ongoing during fieldwork. As these relationships developed the kinds of data I was able to gather also changed, from abstract statements about gambling to more personal reflections on family, friends and work. One of the most productive techniques I employed - and the source of many of the quotations that feature in this article - were informal group discussions that might be described as 'focus groups', although they were more flexibly constituted and managed than that term implies. This format reflected my preference to discuss research questions openly with my participants and to involve them in the research process, which I consider to be dialogic (Rabinow 1977) and iterative (Cassidy 2010).

\section{Betting and other gambling activities in the UK}

There are around 8,500 betting shops in the UK and they are a familiar sight on the high streets of almost every town. Betting is a part of a mature, diverse and flourishing legal market for gambling and the British are regularly described as 'a nation of gamblers' (Kuper 2006). According to the authoritative British Gambling Prevalence Survey (BGPS), completed in 2010 and based on more than 7,500 responses, 73 per cent of the adult population had gambled in the previous year. The most popular form of gambling was buying tickets for the National Lottery (59 per cent of adults had bought tickets in the previous year), followed by other lotteries ( 25 per cent) and scratch cards (24 per cent). Betting on horse races was the fourth most popular activity (16 per cent). Less popular activities included playing fruit or slot machines (13 per cent), bingo (9 per cent), casino games ( 5 per cent) and poker ( 2 per cent) (Wardle et al. 2011).

Each of these varieties of legal gambling has distinctive, if somewhat fluid, associations. Betting on horses and dogs in cash has traditionally been regarded as gambling for working class men (Chinn 2004; Newman 1972) in the same way as bingo has been seen as gambling for (older, working class) women (Dixey 1982; Downs 2010; Mann 2003). Casinos have retained a tenuous association with the international rich, although in suburban and regional casinos the Chinese and Asian British community are more likely to be over represented (Fisher 2000). According to the BGPS, overall, men were more likely to have gambled in the past year than women ( 75 per cent for men and 71 per cent for women). Gambling participation in the past week showed that bingo was the only activity for which participation was greater for women than for men ( 4 per cent and 1 per cent respectively). Conversely, 5 per cent of men had bet on horseraces in the past week and only 1per cent of women 
(Wardle et al. 2010: 24). Betting is the largest sector of the British gambling industry in terms of gross gambling yield (stakes less prizes), accounting for 53 per cent of the total of $£ 5.7$ billion in 2009-10 (Gambling Commission 2011).

The majority of betting shop users I consulted were habitual users, called 'regulars' in the trade. The BGPS 2010 identified those who spent more than seven hours a month (the top 10 per cent of their sample in terms of time spent gambling) as 'high time' gamblers. The survey found that people who spend long periods of time gambling are disproportionately drawn from the poorest socioeconomic groups (Wardle et al. 2010: 65). The high time betting shop customers I worked with reflected this tendency: 40 of the 60 men and 12 of the 20 women I interviewed regularly were either unemployed or retired. All but two of the men described themselves as 'working class'. The two exceptions self identified as 'middle class' and 'criminal underclass'. A recent report suggested that betting shops were likely to be found in low income areas (Harman 2011). Development officers with intimate knowledge of the markets for betting in London understand that this is where they are likely to find the strongest demand for their products.

\section{Betting shop spaces and rhythms}

Betting shops in London share a common layout and material culture, of racing newspapers fixed to the walls, television screens, four Fixed Odds Betting Terminals (FOBTs - video machines that provide a range of games including roulette), betting slips, pens, chairs and tables in company colours. Branding is highly significant, and the same experiences are replicated in each outlet of the three large firms that dominate the sector. Competition between operators is also strong and advertisements and offers or 'specials' featuring well known sports stars are prominently displayed. The counter is the physical fulcrum of the betting shop, providing a separation between customers and staff and the 'front' and 'back end' functions of the shop. In most of the shops where I worked the counters were framed by 'bandit screens', reinforced glass panels with small gaps through which transactions can take place. Access to the area behind the counter was controlled by a reinforced door opened by a button behind the counter, as one would find in a bank. While electronic payments have rapidly increased in the majority of high street shops, betting shops continue to deal almost entirely in cash, which flows across the counter from customer to cashier, initially into a register (called an Electronic Point of Sale or EPOS), and eventually into a safe. Less regularly, winnings cross the counter in the opposite direction.

There are 1,173 betting shop in London. Among the largest is a 2,200 square foot unit operated by the market leader Ladbrokes, which is located in a Grade II listed building on a prestigious London street and has seven staff and forty 


\section{Rebecca Cassidy}

eight flat screen televisions. Some flagship stores resemble men's clubs with comfortable seating and private areas. In contrast to these large, comfortable central London shops there are small and sometimes dingy shops located on the high streets of depressed suburbs, the perceived clustering of which since the Gambling Act 2005 has caused concern within parliament and the media. ${ }^{2}$ A few bookies appear to have changed little since they were legalized in 1961. The first shop I visited at the start of my fieldwork in south-east London was small enough for perhaps eight people to stand in, contained the racing newspaper pinned on the walls, three antique televisions and one man with a suspicious expression, a can of Special Brew (a variety of strong lager) and a dog. The man behind the counter was wearing a shirt, slippers and pyjama trousers. The windows were blacked out, the door was covered by a plastic curtain and there were no seats. The two men scowled at me until I left. In another of the shops I frequented the floor had to be replaced because people had been urinating in a corner after the toilets were closed following a drugs raid.

A number of qualitative studies of betting shops in the UK have been conducted by sociologists, who identified categories of punters based upon a combination of the timing of their entry to the shop and their behaviour while there (Bruce and Johnson 1992; 1994; 1995; 1996). Neal, for example, distinguished between morning and afternoon punters, lunchtime punters, the unemployed and the homeless (1998). People who exemplified these categories were identifiable when I first entered the bookies. However, as Neal acknowledges, interesting aspects of individual behaviour may be overlooked by categorical assessments of punters, which sharpen distinctions between groups of people that may in fact be flexible, and de-emphasize what people who behave differently in the shop may have in common. In distinguishing between 'regulars', 'professionals', 'compulsives' and 'committed' and 'uncommitted' customers, for example, Saunders and Turner eliminate variation in behaviour over time and speculate on motivations that may not easily be discerned let alone distinguished from each other (Saunders 1983; Saunders and Turner 1987).

Changes in betting shops since 1994 have made categorical distinctions, particularly those based on the timing of visits, less useful. Until the mid-1990s betting operator wisdom dictated that shops should offer approximately forty 'events' each afternoon. Horse and dog races took place according to an annual calendar and daily schedule. Mornings in betting shops were quiet and reflective as people planned and placed their bets, afternoons (when the racing took place) were much busier. Technology and regulation have altered this rhythm. Betting on horses and dogs is now available throughout the day: pictures are beamed in from South Africa and elsewhere during the mornings. Any gaps of longer than ninety seconds between races are filled by 'virtual racing', (animated races base on randomly generated numbers). Numbers 
draws take place twice daily. Bets are available on sports other than racing, including football, tennis, golf, rugby and cricket, as well as events like the television programme Big Brother. In addition, casino games are constantly available on FOBTs. Some events retain their distinctive characters: the Grand National is the most bet upon event in the sporting calendar. ${ }^{3}$ The Cheltenham festival and to a lesser extent, Derby day also provide temporal markers in an otherwise humdrum routine. ${ }^{4}$ In general, however, the vast expansion in the number and variety of events has diminished the seasonal differences and daily rhythms that were identified by previous studies. This change has impacted workers and customers nostalgic for the old days when betting on horses and dogs was the primary activity in shops (Cassidy 2012). As one senior manager told me with a barely concealed sneer, 'I used to work in a betting shop, now I work in an arcade'.

Descriptions of women's use of shops in these studies are conflicting. Saunders and Turner (1987) and Saunders (1983) conducted ethnographic work in Cardiff, Wales during the 1980s and claimed that women outnumbered men during the mornings. Newman, working in London in the 1960s, also suggested that betting shops were feminine spaces in the mornings and masculine spaces in the afternoons, saying that, 'the morning hours from opening time at ten to midday belong to women' (Newman 1972:129). Neal conducted participant observation during the 1990s in three shops in Richmond, a relatively prosperous London borough, and one shop in Wirral in Cheshire. He disputed earlier findings and suggested that:

Only very rarely were women found to outnumber men. The handful of fleeting moments when this was so occurred during extreme lulls in custom, i.e. when only three or four punters were present. (1998: 591)

My fieldwork in London confirmed Neal's findings: women were a minority in shops at all times of the day except when they were virtually empty and women happened to be present. In the five different shops in which I conducted a count over a period of three weeks women constituted between 3 and 18 per cent of customers, and exhibited no significant differences in the timings of their visits.

Betting shops in London are masculine spaces. By this I don't mean simply that the customers are primarily men, (although they are), but that this is a distinctively male place, with a set of rules that codify what men, and by implication, women, do, and should do. That is, a particular way of being a man (and woman) is normative, though of course, not enacted by all men (or women), in the same way, all the time. I am not suggesting that there is a male or female way of occupying space. On the contrary, my argument is that in betting shops there is an unevenly distributed and observed understanding of how men and women should behave. This prompts the following questions: 'How are punters and staff produced in this place?' 'What does the 


\section{Rebecca Cassidy}

performance of a punter, or a cashier involve?' and 'How is one rewarded for this performance?' I begin by describing how my research participants accounted for the dominance of men in betting shops by referring to the legalisation of betting shops in 1961.

\section{Early betting shops}

My research participants often described the contemporary male dominance of betting shops as the inevitable result of a historical association between betting and working class men. John, a forty five year old joiner working in the informal economy, spent his lunches, weekends and free afternoons in the shop and told me:

Betting has always been a man's thing. Women never done it in the past ... It was a man's thing then is what I'm saying. Always has been. Me grandad and me dad and that. They bet their whole life. Me mum never did, like. It's one of them things. Men bet. Women cook and that. If they want to go out they'll go down the bingo.

Alistair, another middle aged regular who worked intermittently as a tiler, agreed with him readily:

It's somewhere for men. Betting was their thing see. On a Saturday, of an afternoon, after work. You couldn't talk to a woman about horses. She wouldn't know what you were on about! It's always been like that.

The evidence gathered by social historians McKibbin (1979), Huggins (1999, 2003) and Chinn (2004) suggests that the exclusivity of this association has been exaggerated. According to Chinn, unlike pitch and toss and cards, 'off course betting was not a gender specific activity' (2004: 145). Evidence submitted to the 1923 House of Commons Select Committee on Betting Duty and the 1932/3 Royal Commission on Betting and Lotteries suggested that participation in betting by women was widespread and increasing. A 1926 report claimed that more than half of the women in one poor district in Liverpool had the 'betting habit' (quoted by Huggins 2003: 75).

After the second world war, the thriving business of betting in cash took place on street corners and in factories with illegally operating 'street' bookmakers who sent 'runners' to collect bets from factories, docks and the homes of punters, returning winnings the following day (Chinn 2004). By the late 1940s, the inability of the police to enforce the unpopular ban on street betting was undermining their authority, particularly in working-class neighbourhoods. In 1951, the Royal Commission on Betting Lotteries and Gaming, with the support of the police and the Home Office, advocated legalizing betting shops. The 1960 Betting, Gaming and Lotteries Act legalized shops. The 
intention enshrined in the legislation was not to create new business, but merely to accommodate existing demand, thereby eliminating the illegal market. The shops were to be Spartan at best: the original bill forbade loitering, radio and television. Seats were eventually permitted, when some people argued that the shops would be so austere that they would fail to attract any custom at all. According to my participants, the shops became gendered in a way that betting with illegal bookmakers had not been.

I was introduced to Ethel, a 76 year old woman, by her son, Phil. Ethel managed Phil's hardware shop in the afternoons while he spent time in the bookies next door. Referring to the impact the legalization of betting shops had upon her betting, Ethel told me, 'Oh, it was completely different.' Having once given her bets directly to Harry, the local illegal street bookmaker, she instead gave them to Reg, her husband, to place at the shop. Ethel continued:

At first we all went down [to the shop] to have a look. Well, it was nothing to write home about. I know I wouldn't want my mum to see me there. It felt different somehow. Of course I was used to someone calling for my bets at home, like. Like my mother. Oh no, we didn't go out and bet, we had someone call round and take them. That's right. We'd see 'em the next day if they [the bets] were any good. (Ethel, south-east London, interviewed 2007.)

Reg, Ethel's husband, agreed:

Even in them early days betting shops weren't really set up for ladies. They was very plain, you know. Not much there, just the blower and the papers. They were a bit low to be honest. A bit of an acquired taste! (Reg, 88, south-east London, interviewed 2007. $)^{5}$

The practice of 'runners' calling at individual homes to collect bets, described by Hogge (1905) and in evidence to the 1923 Select Committee was also legalized by the Betting, Gaming and Lotteries Act, but it appears that as the majority of day to day business moved to the shops the practice became less prevalent. The creation of a single place for betting, which replaced the numerous options of illegal betting on streets, in pubs, places of work, homes, newsagents and even fish and chip shops (Chinn 2004: 124) created greater possibilities for gender segregation. Writing ten years after their legalisation, Newman described London betting shops as a world in which, 'strong, rigid, sex differentiation continues to exist, the male and female universe follow different paths, their separation almost retaining forms of ritual avoidance' (1972: 129). Like Newman, my research participants described early betting shops as stigmatized spaces where an activity that was barely tolerated took place between working class men, literally and figuratively out of sight. 


\section{Maintaining masculinities}

Hegemonic masculinities are reproduced and maintained through everyday forms of cultural production. Morris, for example, studied the transmission of gendered differences in academic perceptions in a predominantly white, lower income school in Kentucky (2008). His observations of informal discussions among students enabled him to see how an ideal of masculinity was reinforced during the most ordinary academic tasks. For example, writing a story, one boy rejected Morris's suggestions for improvements saying 'Naw. I don't want to put in a lot of extra effort like that. I'll just do the basic stuff and get a B.' Two other boys supported his decision saying, 'Yeah, I hate these pussies who make like an A minus and then they whine about it.' And 'Yeah it's like why do you care? Why does it have to be better? Nothin' wrong with a normal grade!' (2008: 738). Like the working class 'lads' Willis worked with in the West Midlands of England (1977) these boys rejected the ideal of educational achievement as a path to improvement by rendering it feminine. At their school in Kentucky, 'hegemonic practices of masculinity ... focused on a carefree, almost rebellious attitude toward schoolwork, and physical toughness exemplified by manual labor.' (Morris 2008: 741). Newman described a similar set of ideas in betting shops in London during the 1960s where men were apparently: 'resolute, independent yet cooperative, humorous, modest, indifferent in the face of danger and adversity' (1972: 23). He referred to this working-class masculinity as a 'universal male ethos' and described how it was preserved in shops:

Each subtle nuance of action and reaction will undergo the litmus test of judgement by equals, will serve, not as on first impact one might be inclined to assume ... to separate the leaders from the mass in competitive encounter, but rather to sustain common values, to confirm the image of what man ought to be like. (1972: 23)

Newman's work reflected his interest in championing the betting shop as the last bastion from which to resist what he referred to as the 'emborgoisement' of the 'viable, homogenous, working class' (1972:17). His work is a celebration of, rather than a critical exploration of the masculinity that he universalizes. However, similar ideas continue to circulate in betting shops today. Regulars discouraged attitudes and activities that were gendered female (including budgeting, complaining, jealousy, nagging and talking too much) and encouraged others that were gendered male (including generosity, a carefree attitude and righteous anger).

Working with trainee teachers, Brown and Evans have shown how the legitimate qualities of male physical education teachers are transmitted through a pedagogy which is reinforced around a gendered persona that includes, 'demonstrable practical sporting ability; a competitive sports 
orientation; informality; fun, jokes, and pranks; spontaneity; strength and independence; strong discipline when necessary; and an implicit demand for respect based on these qualities' (Brown and Evans 2004: 57). The hegemonic masculinity of betting shops is also maintained through everyday practices that merge into the background as elements of the particular habitus exhibited by betting shop workers and customers. Where physical education teachers should exhibit sporting ability, betting shop regulars emphasized the mastery of intellectual skills, particularly the esoteric language of horse racing and betting. Although it is simple to place a basic bet by making a random choice and asking for help from a cashier, this is a performance that would prompt scorn in habitués. Sophisticated betting combines an assessment of the relative merits of a horse or a sports team, deduction of the probability of different outcomes and calculation of the stake to be risked on such eventualities. The bet is not the only important part of the process, but how the decision is reached. In this way losing bets were a source of pride and respect, while lucky wins attracted criticism. Over-celebration was also discouraged. When Mark, a relative youngster among the regulars, began to strut and puff his chest out after landing a win he was shunned by the rest of the group, who left his high fives hanging and turned their backs on him. When I asked Frank, a more senior regular, what was going on he told me that:

We're bringing Mark down a peg or two. Any fuckin' idiot can back a winner or two. He's got to pull his head in - same as the rest of us. You can't get above your station here.

Mark gradually learned to celebrate in the same casual, magnanimous fashion as the rest of the group.

As well as mastering the technical and social aspects of betting, winning and losing, regulars also became skilled at exchanging playful, sexual comments with female cashiers described as 'banter'. According to Leech, banter is a form of mock impoliteness, or 'an offensive way of being friendly' and the opposite of irony which is 'an apparently friendly way of being offensive' (Leech 1983:144). In betting shops, sexual banter used up a great deal of time and energy each day. Men conventionally referred to women as 'love', 'darling' and 'babe' and continually evaluated their physical appearances. Pressure to 'play along' took many forms. When I worked as a cashier men would chide me by saying, 'Oh come on darling, be a good sport, give us a smile. It might never happen!' Female colleagues sanctioned this behaviour by diminishing the importance of sexual remarks, saying, 'He doesn't mean anything by it'. As my female manager told me, 'I don't mind if the men have a little bit of a look and that. They don't mean no harm. Be worse if they didn't give me the time of day. Then I'd be worried.' Some punters told me I was 'stuck up', using class to explain my resistance to playing a part in the exchange of sex talk, others as 


\section{Rebecca Cassidy}

'frigid'. By refusing the only role offered to me, my femininity became open to question.

As well as exchanging banter, some male customers developed relationships with female workers based upon gifts and the sharing of personal information. In all of the shops I worked in at least one or more regulars would bring 'treats' to the female staff, including coffees, fried chicken, chocolates and cakes. Many would also give 'luck money' to female staff if they had a big win. Because I was known to be interested in people's opinions I was often the victim of what my colleagues and I came to refer to as 'inappropriate sharing'. I asked one punter not to tell me about his pornography collection and his haemorrhoids. A female colleague banned a punter from her shop after he wrote and recorded a CD of songs for her. Explicit sexual banter was acceptable, intimacy was not. As I will describe in more detail in the next section, female staff distinguished between what went on between customers and staff in the shop and their 'real' relationships outside.

Men and women also negotiated their relative positions using more explicitly coercive tropes. I became accustomed to being shouted at for being slow to take bets or making mistakes, real or imagined, in taking those bets. I relied on my manager to back me up during these times, but also on regulars. I recorded a typical example of verbal abuse that might occur three or four times in a week in my notebook:

11.40 Monday. Lemons called me a fucking whore and smashed down his slips and pen on the counter. David (my manager) told him quietly to watch his language. Ruben (a regular) said 'easy mate'. Lemons left the shop and no one referred to it again.

Sexual violence was also a 'threat' invoked by male and female colleagues and punters. During my observation of shops, I was continually warned about dangerous men, propositioned and followed home on several occasions, all examples of 'censures' that served to reinforce the terms on which my encounters in the shop took place (Roberts 1993, see also Bird 1996). As Roberts argues, censure operates to "divide the "good" and the "bad" ... Censures are a red light, a hand signalling "stop" ' (1993:171). In this case, the signal was less direct, but the implication was clear, by spending time the shops without a husband or male protector I had made myself vulnerable to the threat of violence.

Gendered ideas about betting shops are also cultivated and legitimated outside the shops through interactions with relatives and friends. Of the 80 regular punters I interviewed repeatedly during fieldwork (60 men, 20 women), only ten failed to identify their first experience of betting as having been initiated by a relative or friend of the same gender. Many of my research participants had taken an interest in their father's betting, as had Angus, aged 
18, who told me simply that, 'Me dad liked a bet and he taught me what's what.' Not all fathers shared their knowledge as freely, and some actively discouraged their sons from betting:

My brother took me. He showed me the betting slips and that. My dad went mad. When he found out we'd been to the bookies he took me to one side and he said, 'It'll come to no good!' And he was right. But he couldn't say nothing because I knew he was down the dogs all the time. I was 16 then. (Pete, 40, refuse collector, south London, interviewed three times between 2006 and 2009).

Some men presented a visit to the shop as a rite of passage marking progress from childhood to adulthood, from being contained by a domestic environment often envisaged as dominated by women to a world of singular, masculine individuals, unconstrained by responsibilities other than those to their 'mates'. Ron, for example, a fifty year old unemployed builder explained during one of our group discussions:

Betting makes a man of ya. You go in what 15, 16, with your mates. You aint got no women there. No apron strings. You make your own mind up about something and you back it up with your own money. We used to have a thing round our block. When we all knew each other and that. We used to say the first pay packet you picked up when you was a young lad you took it to the bookies. Like losing your virginity. You either did it or we took it and did it for you. It makes a man of ya. None of these fuckin poofs around 'ere now. (Extract from a group discussion in a betting shop in central London 2007)

The explicit violence of this description emphasizes the constraints placed upon by men by other men in this context and evokes other examples of ritual violence to which men subject one another, women and animals in order to make good their masculinity (Campbell 2000; Enloe 1993; Evans, Gauthier and Forsyth 1998). It merges sex, violence and betting and frames them as catalysts for the break to manhood from the domestic, feminine world of 'apron strings' and 'fuckin' poofs.'

The majority of the violence I observed during fieldwork was limited to angry verbal exchanges, pushing and shoving. I also recorded seven more serious incidents, ranging from two men fighting after a disagreement, to a brawl which damaged furniture and spread out into the street. I saw only one weapon, a knife brandished as a warning, and blood was spilt on four occasions. The police attended the brawl, the other fights were stopped by staff and customers. Some of this violence was directed towards staff. A man who threatened a female colleague with a golf club was roughly ejected by other customers, an event which anticipated an incident in 2013 when a man attempting to rob a betting shop in Plymouth died after being restrained by regulars, one of whom said at the time: 


\section{Rebecca Cassidy}

They would do that in a shop like this, it is our betting shop ... The staff become your friends, it's a little family, and it's no different to a member of your family being threatened (Sawer 2013).

Some of the Plymouth regulars didn't even notice that an attempted burglary had taken place: 'When I walked in they were on the floor. They were scuffling but I just thought it was a fight' one said. Low level violence of this kind was also unexceptional in the betting shops where I worked.

\section{Women and betting shops}

In their reappraisal of the concept of hegemonic masculinities, Connell and Messerschmidt emphasize that they are not exclusively maintained by men (2005: 837). In this section I show how, in betting shops, women discipline both other women and men who fail to meet their expectations. This should not imply that the women I describe endorse this hegemonic masculinity in every aspect of their lives. Their actions relate to ideas about appropriate behaviour in betting shops. They are not unusual in endorsing various ideas of masculinity. Talbot and Quayle, for example, have shown how during interviews that focus on work, social, family and romance, female South African University students described distinctive male and female qualities in each context and were "particularly willing to accept subjugation to engage in ideals of romantic partnership congruent with emphasized femininity' (2010:255). In this case, the masculinity that women endorsed and upheld in betting shops did not always reflect their ideas outside this space.

In March 2006 I joined five other female recruits training to become betting shop cashiers at the Head Office of a large company. Deborah, our enthusiastic guide, had worked in the industry for twenty-five years, and was eager to share her experiences with us. During three days we have been told about the company, its products and our responsibilities. As we left, Deborah gave us what she refers to as a final 'pep' talk, a condensed version of the previous three days: 'Don't forget girls!' she said energetically (to a group of women who ranged in age from 21 to 45$)$ :

Always smile when a customer walks in the door. If you can't remember his name, say 'Hello Darling'. Be cheerful. Say 'Good Luck' when you take his bet. If they don't want to talk that's fine. If they do talk to you, don't give your opinion, they all know a lot about racing, just agree with them. Don't forget they've come in the shop to get away from their wives, they don't want you nagging them. They're men! They want to be left in peace! Even though you're a woman you have to try to think like a man, and ask yourself what he wants. Be a woman, act like a woman, but a man's woman. 
Cashier training rewarded and encouraged certain kinds of behaviour, suppressed and discouraged others. Even before we began work, Deborah had instilled in us the idea that we had to be friendly, well turned out and feminine as well as competent. The exact nature of the emphasized femininity (Messner 2002) that we were expected to strive for became clearer as we grew in experience.

Beryl, a 58 year old cashier 'on and off' for thirty years, continued my training 'on the job'. Beryl was friendlier and more welcoming to men who came into the shop than she was to women. When I asked her to explain her treatment of female customers, she told me that:

I ain't one for women in the shops. 'Why don't you fuck off down the bingo?' That's what I say. But then I'm old fashioned. My dad would always put me mum's bets on for 'er. Even the (Grand) National. She weren't let in the shop, me mum wasn't. Not once. She stood outside when the race was on.

Beryl makes a distinction between women's presence in shops as customers (morally questionable) and as cashiers (morally acceptable). Her attitude is one that I encountered among many betting shop workers who appeared to accommodate ideas about gender in the shops that they did not necessarily apply to the rest of their lives. Beryl was the sole wage earner in her household, responsible for both her husband, who was unable to work after an accident, and her grandson who lived with them. At home, Beryl was confident in her role as provider, and maintained the family car, the house and garden. When a neighbour commented on her climbing a ladder to clean the front windows, for example, she replied, 'How else is it going to get done? I don't see you offering to come round do I?' Beryl didn't regard her opinion that betting shops were more suitable places for men than for women as contradictory to her having adopted a traditionally male role at home. Gendered performances were, for Beryl, piecemeal and formed and located in particular contexts and circumstances.

Some working-class women in London presented betting shops as part of a wider masculine geography and culture that was separate from, and contrasted with, their own. In one of the neighbourhoods in south-east London where I conducted fieldwork the mothers, wives and sisters of the men who bet in the bookies could be found in the pub next door, which they described as having become increasingly accessible to women as the betting shop became less so. One group I came to know well over a period of three years, met on Saturday afternoons to eat fish and chips in the pub while the men dashed in and out to the bookies. During our discussions, men and women described their interests and activities as separate. Bob presented the shop as an enclave from which he could resist the demands made upon him by his wife, Shirl:

The bookies is me office. Shirl has her bingo, her shopping and the kids. I don't stick my nose in that and she does the same with me betting. 
She ain't interested anyway. (Bob, retired train driver, 66, south-east London)

Shirl revealed how women reproduce knowledge about betting shops as masculine spaces:

I don't bother about betting. Apart from the National, I have a little flutter on that. But betting was always a man's world wasn't it? Me dad and me uncles were all into it alright, but me mum was like 'that's not for you. It's just something for the men.' You don't want to get yourself mixed up with the betting shop crowd and that. And I never did. (Shirl, 64, mother and wife, south-east London $)^{6}$

Shirl was not fearful of betting shops, merely convinced that they were 'not for her'. However, for some people, betting shops were 'dangerous places' occupied by 'unpredictable strangers' (Lupton 1999). At a hearing for a betting shop licence application, for example, a woman who described herself as 'a university-educated housewife and mother' told me that she had never been into one and didn't know anyone who had, but betting shops were full of 'drug addicts and homeless people' and that gambling was 'a sign of hopelessness, a cry for help'. A petition opposing the new betting shop included an entry which stated that the shop would attract 'skagheads, winos and the culturally poor."

\section{Betting as maths}

The idea that betting was an activity that was suitable for men (and thus, by implication, unsuitable for women) was forcefully communicated by both men and women. Despite this, the consistently differing rates of participation of men and women in particular forms of gambling were regularly presented to me as a reflection of their essential aptitudes, preferences and interests. As Griff, a regular, explained:

Men are always going to be better at maths and science. Women are better at taking care of children. They don't want a hobby that's about working out probability and risk. That's why they like bingo and the lottery. There's nothing to work out. It's just 'oop' up pops another number. She can understand that and she doesn't need to work out whether to go each way or nothing like that. She's happy with that. Men need something to get their teeth into. It's just natural. It's the way we're built. (56, council worker on long-term sickness benefit, central London. Interviewed in 2007.)

According to these views, familiar from many other contexts, women are both 'naturally' part of the domestic sphere (Rosaldo 1974) and also content to deal with games based on random events over which they have no control. Men are 
more individual, seek control and relish tasks that require calculation, abstract reasoning and the accumulation of facts. In positing this binary opposition, discourses about betting resemble those about mathematics (Fennema and Leder 1990; Mendick 2006; Willis 1989, 1990) and other typically 'masculine' activities including engineering and politics.

Ideas about differences in numeracy between men and women were easily elicited during interviews and discussions. They provided a naturalized explanation for the relative dominance of men in betting shops which focused on the choices of women. Women preferred something else, I was told. It was not that they were excluded (by men), on the contrary, they were welcome, but they just wouldn't enjoy adding up and counting. As Frank, a regular I interviewed over a period of three years, told me, 'Women can come in, but they don't because they find it boring. It's too technical. They don't know about horses or bets and they get bored. It's not that we don't want them in here. They just don't bother.'

These ideas also emerged strongly during discussions about recruitment. Despite the presence in shops of extremely able and numerate female managers, senior managers, staff and punters consistently referred to different qualities in men and women. Women should be 'friendly' and 'easy on the eye'. Men should 'know their stuff'. During one lunch time meeting, Gerald, a sixty year old senior manager who had worked in the betting industry for over forty years was exasperated by what he saw as a tendency for his female colleague in Human Relations to hire good looking young men as cashiers, rather than what he called 'totty'. He continued, 'What's the point of that? I mean, no one's gonna come into the shop to look at great big hairy blokes are they?' ${ }^{8}$ Tracy, a 45 year old regional manager, who had worked in the industry for 20 years, contributed at this point. She was doubtful that women were equally skilled in the 'business' of betting: knowledge of horse racing and the ability to calculate complicated bets:

You get a lot of young girls coming in for the summer or whatever. They don't know anything about horses or dogs. They don't get any training ... They might be good looking, punters might like having a chat with them, or that, but ... Girls don't know about racing. They don't naturally do the figures. You see a lot of men who just it comes naturally to don't you. Not the girls as much. Interesting that.

Deirdre, a trainee manager, responded:

Yes but I know that the figures don't come as easily to me as they do to Martin, but I work harder. And I'm better at customer service. Martin will sit behind the counter and watch the racing. I'll get up and talk to people, say 'hello' when they come in the shop, fetch them a coffee or whatever.

In 2008, the Chief Executive of a betting shop chain used the introduction of electronic point of sale (EPOS) technology to account for the rise in the 
Rebecca Cassidy

number of women finalists in the competition for the Betting Shop Manager of the Year saying, 'They've done away with traditional settling (calculating winnings), which was usually done best by men. Now the emphasis is on customer service, which is where women come into their own.' (quoted by Wright 2008). According to these arguments, men and women could both excel as betting shop managers, but for different reasons. Specifically, women were better at the 'soft skills' of customer service, making people feel welcome and being responsive. Men excelled in the 'harder' skills: calculating the returns of bets and acting as repositories of specialized knowledge about horse racing and betting. Staff recruitment and training reproduced conventional ideas about appropriate behaviour for men and women. It also reproduced a conventional association between men and women and certain gendered and differently valorized aptitudes. ${ }^{9}$

\section{Conclusions}

Kimmel has suggested that a 'crisis of masculinity' in the USA in the late nineteenth century prompted a rise in 'manly pursuits' including outdoor clubs and sports (2005). In London, betting shops provide a setting in which masculinities based on traditional working-class ideas of gender can be imperfectly preserved, reworked and resisted. The incentives to 'break down the walls' of betting shops are less obvious than those that surround participation in other traditionally male dominated activities including sports, entertainment, business and politics. Unlike these activities, which are, in theory at least, subject to shared public standards that condemn sexism (as well as other kinds of discrimination) betting is easily dismissed as trivial, morally ambiguous and inconsequential. As a result of this lack of critical attention, betting shops have been able to provide a 'haven' for the performance of a particular kind of masculinity.

Participants in my research attributed the male dominance of the betting shop to a natural preference by men for activities that involve calculation and deduction and to the absence of this preference among women. However, the idea that betting in cash off course is an exclusively male working-class pursuit misrepresents a practice that was once far more widespread. When betting shops were legalized in 1961 the cross class/cross gender appeal of betting was imperfectly preserved. A cult of masculinity grew up around the shops, aided by enclosure and the lack of visibility and ventilation that regulation required. An image of fraternal exclusivity was enhanced and maintained by the ways in which betting knowledge was shared and the construction of the betting shop as a place that stood in contrast to the femininity of home or the bingo hall.

Mundane everyday exchanges support the masculine geography of betting. In the London neighbourhoods where I conducted fieldwork, women banished 
themselves from betting shops, rejecting their smelly embrace in favour of a booth in the pub or a table in the caff. If they wanted to have a flutter they might pop in but they were more likely to 'stick to the lottery' or 'go down the bingo' with (female) friends. Inside shops, staff recruitment and progression sought and rewarded different qualities in men (numeracy and knowledge of racing) and women (friendliness and physical attractiveness). As a cashier working in betting shops I was taught how to behave as a woman by punters and colleagues who coached me in sexual banter and submissiveness ('customer service'), telling me to 'lighten up' at the same time as they warned me about 'dodgy blokes' to be avoided. As a visitor to shops my treatment by fellow customers varied. I was sometimes forced to leave by stares, grumbles and physical shoves, sometimes taken under the wing of a (male) elder as a kind of exotic pet. As a woman, I didn't have a place inside the betting shop unless I was behind the counter.

The hegemonic masculinity that I observed in London's betting shops is partly a reflection of a more generic idea of men as numerate, intelligent and potentially dangerous. However, it is also residual in the sense that it survives despite the many alternative, less binary, less hierarchical, more fluid ideas about gender that are available on London's streets. It has persisted because the betting shop was initially isolated physically and morally from the rest of life on British high streets. By the time shops were opened up by legislation during the 1990s, and gambling became less stigmatized, recategorized by the state as a form of leisure to be consumed, rather than a vice to be controlled, betting on horses had been established as an activity 'for' men, in the same way as bingo was 'for' women. More recently, the internet, smart phones and tablets have provided access to a huge variety of gambling products without any need to visit specialized shops. Under these dynamic technological and regulatory circumstances it seems likely that betting shops will remain masculine spaces, if they survive at all.

(Date accepted: September 2013)

\section{Notes}

1. I'm grateful to both betting operators for granting me access to their shops and to staff and customers for their time and patience. The names of research participants have been changed in accordance with their wishes. Fieldwork was supported by the Economic and Social Research Council and the Responsibility in Gambling Trust, grant reference RES-164-25-0005. Writing up has taken place with support from the European Research Council, grant reference GAMSOC 263433.

2. In 2007 the London Evening Standard described what it referred to as a 'Betting Shop Boom', caused by the eradication of the 'demand principle' which limited the supply of betting shops to a level thought to meet existing demand in a particular area. See also Hackney Council 2007 and Harman 2011.

() London School of Economics and Political Science 2013 


\section{Rebecca Cassidy}

3. The Grand National is the most popular betting race of the year in the UK. Half the adult population bet on the race each year.

4. The Cheltenham festival is an important jump racing meeting held each March. The Derby is Britain's richest horse race and one of the five 'Classic' races of the flat racing season, held at Epsom in June.

5. The 'blower' referred to the public address system that relayed results through from the racecourses.

6. A 'flutter' is British slang for a bet. It implies an inconsequential, occasional, low stakes bet.

7. The licensing hearings I attended in the borough of Greenwich were dominated by middle class women. However, working class women and working and middle class men have also spearheaded or contributed to campaigns against the granting of licenses for new betting shops in low income areas. See, for example, Hackney Council (2007).

8. 'Totty' describes good looking people, particularly women, and in the betting shop also suggests sexual availability.

9. For a comparison of the labour required of croupiers and machine minders in casinos in Australia see Austrin and West (2005). Although gender is not the explicit focus of this article, it is another example of how the regulation of gambling impacts upon workers, in this case exposing them to particular kinds of surveillance.

\section{Bibliography}

Armytage, M. 2001 'Tanya is a Maiden for the Notebook', Daily Telegraph, 18 May: 74. Austrin, T. and West, J. 2005 'Skills and Surveillance in Casino Gaming: Work, Consumption and Regulation', Work, Employment and Society 19: 305-26.

Bird, S. 1996 'Welcome to the Men's Club: Homosociality and the Maintenance of Hegemonic Masculinity', Gender \& Society 10(2): 120-32.

Brown, D. and Evans, J. 2004 'Reproducing Gender? Intergenerational Links and the Male PE Teacher as a Cultural Conduit in Teaching Physical Education', Journal of Teaching in Physical Education 23: 48-70.

Bruce, A. and Johnson, J. 1992 'Toward an Explanation of Betting as a Leisure Pursuit', Leisure Studies 11: 201-18.

Bruce, A. and Johnson, J. 1994 'Male and Female Betting Behaviour: New Perspectives', Journal of Gambling Studies 10: 183-98.

Bruce, A. and Johnson, J. 1995 'Costing Excitement in Leisure Betting', Leisure Studies 14: 48-63.

Bruce, A. and Johnson, J. 1996 'Gender Based Differences in Leisure Behaviour: Performance, Risk-taking and Confidence in
Off Course Betting', Leisure Studies 13: 65-78.

Campbell, H. 2000 'The Glass Phallus: Pub(lic) Masculinity and Drinking in Rural New Zealand', Rural Sociology 65: 562-81. Cassidy, R. 2002 Sport of Kings: Kinship, Class and Thoroughbred Breeding in Newmarket, Cambridge: University Press.

Cassidy, R. 2010 'Gambling as Exchange: Horse-race Betting in London', International Gambling Studies 10(2): 139-49.

Cassidy, R. 2012 'Battles in the Betting Shop', Journal of the Royal Anthropological Association 18(2): 266-84.

Chinn, C. 2004 Better Betting with a Decent Feller: A Social History of Bookmaking, London: Aurum Press.

Connell, R. 1987 Gender and Power, Oxford: Polity Press.

Connell, R. and Messerschmidt, J. 2005 'Hegemonic Masculinity: Rethinking the Concept', Gender and Society 19(6): 829-59. Dixey, R. 1982 Women, Leisure and Bingo, London: Trinity and All Saints College Press.

Downs, C. 2010 'Mecca and the Birth of Commercial Bingo 1958-70: A Case Study', Business History 52(7): 1086-106. 
Enloe, C. 1993 The Morning After, Berkeley: University of California Press.

Evans, R., Gauthier, D. and Forsyth, C. 1998 'Dogfighting: Symbolic Expression and Validation of Masculinity', Sex Roles 39: 825-38. Fennema, E. and Leder, G. (eds) 1990 Mathematics and Gender: Influences on Teachers and Students, New York: Teachers College Press.

Fisher, S. 2000 'Measuring the Prevalence of Sector-Specific Problem Gambling: A Study of Casino Patrons', Journal of Gambling Studies 16(1): 25-51.

Gambling Commission 2011 Gambling Industry Statistics 2009-10, available at: http:// www.gamblingcommission.gov.uk/pdf/ Gambling \%20Industry\%20Statistics \%20 2009\%202010\%20WEB\%20-\%20January \%202011.pdf. [Accessed 10 January 2012]

Goodlad, I. 2008 'The Rise of the Female Bookmaker', BBC News website, April 18, available at: http://news.bbc.co.uk/1/hi/ scotland/glasgow_and_west/7354169.stm.

[Accessed 25 March 2011]

Gottdeiner, M. 2005 'Masculine Space' in M. Gottdeiner and L. Budd (eds) Key Concepts in Urban Studies, London: Sage.

Hackney Council 2007 'Hackney vs. the Bookies', Hackney News and Events, May. Available at: http://www.hackney.gov.uk/xcnews-may07-hackney-vs-bookies.htm

[Accessed 11 January 2012]

Halberstam, J. 1998 Female Masculinity, Durham: Duke University Press.

Harman, H. 2011 The Problem of Betting Shops Blighting High Streets and Communities in Low Income Areas, London: House of Commons. Available at: http://www. harrietharman.org/uploads/d2535bc1-c54e6114-a910-cce7a3eff966.pdf. [Accessed 10 January 2012]

Hogge, J. 1905 'Gambling Among Women' in B. S. Rowntree (ed.) Betting and Gambling: A National Evil, London: Macmillan. van Hoven, B. and Hoerschelmann, K. (eds) 2005 Spaces of Masculinity, New York and London: Routledge.

Huggins, M. 1999 Flat Racing and British Society 1790-1914: A Social and Economic History, London: Routledge.
Huggins, M. 2003 Horseracing and the British 1919-39, Manchester University Press.

Kimmel, M. 2005 The History of Men: Essays on the History of American and British Masculinities, Albany, NY: State University of New York Press.

Kuper, S. 2006 'A Nation of Gamblers? You Bet!' The Financial Times, April 22.

Leech, G. 1983 Principles of Pragmatics, London: Longman.

Levin, P. 2004 'Gender, Work and Time: Gender at Work and at Play in Futures Trading' in C. Fuchs Epstein and A. L. Kalleberg (eds) Fighting for Time, New York: Russell Sage Foundation.

Lupton, D. 1999 'Dangerous Places and the Unpredictable Stranger: Constructions of Fear of Crime', The Australian and New Zealand Journal of Criminology 32: $1-15$.

Mann, K. 2003 ، "Sit Anywhere You Like, We're All Friends Together": Reflections on Bingo Culture', Goldsmiths Anthropology Research Papers 8, London, UK.

McKibbin, R. 1979 'Working-class Gambling in Britain 1880-1934', Past and Present 82: $147-78$.

Mendick, H. 2006 Masculinities in Mathematics, Buckingham: Open University Press.

Messerschmidt, J. 2012 'Engendering Gendered Knowledge: Assessing the Academic Appropriation of Hegemonic Masculinity', Men and Masculinities 15(1): 56-76. Messner, M. 2002 Taking the Field: Women, Men and Sports, Minneapolis, MN: University of Minnesota Press.

Morris, E. 2008 " "Rednecks", "Rutters", and "Rithmetic": Social Class, Masculinity, and Schooling in a Rural Context', Gender \& Society 22: 728-51.

Neal, M. 1998 “"You Lucky Punters!” A Study of Gambling in Betting Shops', Sociology 32: 581-600.

Newman, O. 1972 Gambling: Hazard and Reward, London: Athlone.

Pentinnen, E. 2008 Globalization, Prostitution and Sex-Trafficking Corporeal Politics, London and New York: Routledge. 


\section{Rebecca Cassidy}

Potter, S. 2004 'Stevenson On Course to Stay the Distance', The Times, 26 February: 69.

Rabinow, P. 1977 Reflections on Fieldwork in Morocco, Berkeley and Los Angeles: University of California Press.

Roberts, P. 1993 'Social Control and the Censure(s) of Sex', Crime, Law and Social Change 19(2): 171-86.

Rosaldo, M. 1974 'Woman, Culture and Society: A Theoretical Overview' in M. Rosaldo and L. Lamphere (eds) Woman, Culture and Society, Stanford University Press.

Saunders, D. 1983 'Gambling in Wales: The Case of Off Course Betting', Welsh Journal of Business and Administration 4: 32-42.

Saunders, D. and Turner, D. 1987 'Gambling and Leisure: The Case of Racing', Journal of Leisure Studies 6: 281-99.

Sawer, P. 2013 'Masked Armed Robber Dies After Being Pinned Down' The Telegraph, 26 January.

Talbot, K. and Quayle, M. 2010 'The Perils of Being a Nice Guy: Contextual Variation in Five Young Women's Constructions of Acceptable Hegemonic and Alternative Masculinities', Men and Masculinities 13: 255-78.

Wardle, H., Moody, A., Spence, S., Orford, J., Volberg, R., Jotangia, D., Griffiths, M., Hussey, D. and Dobbie, F. 2011 The British Gambling Prevalence Survey 2010, National Centre for Social Research.

Willis, P. 1977 Learning to labor: How Working Class Kids Get Working Class Jobs, New York: Columbia University Press.

Willis, S. 1989 Real Girls Don't Do Maths: Gender and the Construction of Privilege, Geelong, Victoria, Australia: Deakin University.

Willis, S. 1990 'The Power of Mathematics for Whom?' in J. Kenway and S. Willie (eds) Hearts and Minds: Self-esteem and the Schooling of Girls, London: The Falmer Press.

Wright, H. 2008 'Girl Power in New Era', The Racing Post, 28 November: 31. 


\section{AUTHOR QUERY FORM}

Dear Author,

During the preparation of your manuscript for publication, the questions listed below have arisen. Please attend to these matters and return this form with your proof.

Many thanks for your assistance.

\begin{tabular}{|l|l|l|}
\hline $\begin{array}{l}\text { Query } \\
\text { References }\end{array}$ & Query & Remarks \\
\hline 1 & $\begin{array}{l}\text { *AUTHOR: To match the reference list, } \\
\text { should Wardle et al. 2010 be changed to } \\
\text { Wardle et al. 2011? Please advise. }\end{array}$ & \\
\hline 2 & $\begin{array}{l}\text { *AUTHOR: Kentucky (2008) has not been } \\
\text { included in the Reference List, please supply } \\
\text { full publication details. }\end{array}$ & \\
\hline
\end{tabular}

Note: The query which is preceded by * is added by Toppan Best-set. 